\title{
PENGGUNAAN KARBAMID PEROKSIDA SEBAGAI BAHAN PEMUTIH GIGI
}

\author{
Endang Suprastiwi \\ Departemen. Ilmu Konservasi Gigi Fakultas Kedokteran Gigi Universitas Indonesia
}

Endang Suprastiwi. Penggunaan karbamid peroksida sebagai bahan pemutih gigi. Indonesian Journal of Dentistry 2005; 12(3):139-145.

\begin{abstract}
Carbamide peroxide as a whitening agent for teeth is very popular because the use of this agent is easy and inexpensive. There are two kinds of concentrations, i.e. $10 \%-15 \%$ and $35 \%$. The methods are home bleaching and in office bleaching. For home bleaching, the duration of whitening application is 2-6 weeks, each day for 8 hours, whilst for in office leaching, two hour application will be required. Whitening efficacy might be increased up to 2-5 levels and the color may sustain for 1-3 years, and this treatment could be reapplied. There is an effect on pulp system, but the effect is reversible, i.e. sensitivity which could be treated with fluoridation or application of potassium nitrate. The side effects on gingiva include inflammation which is caused by the buffer and is only temporary. Bleaching is safe to be use and the result will be satisfying if proper procedure is followed.
\end{abstract}

Keywords: Carbamide peroxide, whitening agent

\section{Pendahuluan}

Dengan makin meningkatnya - permintaan masyarakat yang menginginkan giginya diputihkan, perkembangan penggunaan bahan pemutih untuk gigi menjadi lebih meluas. Ada bermacam-macam bahan pemutih gigi yang digunakan, baik untuk pemutihan gigi secara interna maupun eksterna masing-masing untuk gigi nonvital maupun gigi vital. Penggunaan bahan pemutih eksterna biasanya di lakukan pada gigi vital yang perubahan warnanya menyeluruh pada semua gigi. Metode pemutihan gigi pada kasus tersebut bisa di lakukan sendiri di rumah oleh pasien dengan menggunakan bahan yang di jual bebas atau di bawah pengawasan dokter gigi, atau dengan metode in office bleaching yang penggunaan bahan pemutih giginya dilakukan langsung oleh dokter gigi di ruang praktek. Teknik pemutihan gigi vital pertama kali diperkenalkan oleh Haywood dan Heymann (1989) dengan menggunakan nightguard. dengan bahan pemutih karbamid peroksida $10 \%{ }^{1}$

Ada 2 macam bahan pemutih eksterna yang digunakan : yaitu hidrogen peroksida dan karbamid peroksida. Kedua bahan ini sama-sama mengandung hidrogen peroksida yang akan terurai menjadi $\mathrm{H}_{2} \mathrm{O}$ 
dan $\mathrm{O}_{2}$. Karbamid peroksida merupakan gabungan antara hidrogen peroksida dan urea dan dapat juga disebut urea peroksida. Ada 2 cara pemutihan gigi dengan menggunakan karbamid peroksida yaitu dengan home bleaching dengan karbamid peroksida konsentrasi rendah yaitu $10 \%$ dan $15 \%$, atau pasien membeli sendiri yang dijual secara bebas dan in office bleaching yang pemutihan giginya di lakukan oleh dokter gigi selama 1-2 jam diruang praktek dengan menggunakan konsentrasi karbamid peroksida $35 \%$. Keamanan bahan ini masih diragukan, akan tetapi dengan banyaknya penelitianpenelitian yang dilakukan dan hasilnya memuaskan. Dengan demikian akan dibahas penggunaan karbamid peroksida sebagai bahan pemutih gigi, baik cara penggunaannya maupun efeknya terhadap jaringan gigi dan sekitarnya

\section{Sejarah Pemutihan Gigi}

Pemutihan gigi atau lebih popular disebut bleaching adalah suatu tindakan untuk memutihkan gigi secara kimia dengan menggunakan bahan oksidator kuat yaitu peroksida. ${ }^{1,2}$ Pemutihan gigi sudah mulai populer sejak abad 19. Pada tahun 1850 pemutihan gigi non vital telah dilakukan dengan menggunakan klorida dari kapur dan pada tahun 1864 menggunakan chlorine dari kalsium hidroksida dan asam acetat. Tahun 1877 Chappel memperkenalkan pemutihan gigi dengan menggunakan asam oksalat, dan pada tahun 1884 bahan pemutih hidrogen peroksida diperkenalkan oleh Harlan. Tahun 1895 Garreton menggunakan sodium hipoklorit serta Pierson dengan panas dan hidrogen peroksida, dan kedua perawatan tersebut dinyatakan berhasil. $^{3}$

Sementara itu perubahan warna gigi yang disebut Colorado brown stain (1916) dan merupakan endemic fluorosis dapat ditanggulangi dengan asam hidroklorit Kemudian pada tahun 1940 mulai dilakukan perawatan fluorosis dan noda tetrasiklin dengan menggunakan superoksol yang mengandung hidrogen peroksida $35 \%$ yang dicampur dengan natrium perborat .Bahan ini telah diperkenalkan sebelumnya untuk memutihkan gigi nonvital dengan teknik walking bleach yang sampai sekarang masih dilakukan. ${ }^{4}$ Spasser (1961) memperkenalkan kombinasi air dan sodium perborat, sedangkan Nutting \& Poe mengkombi-nasikan dengan hidrogen peroksida dan 1970 hidrogen peroksida direkomendasikan untuk diskolorasi dentin. ${ }^{4}$
Pada pertengahan abad ke 19 pemutihan gigi mulai dilakukan secara in office untuk gigi vital maupun nonvital, tahun 1968 ketika Kusmier adalah seorang orthodontis dari Arkansas menggunakan Gly-oxide TM pada mouthguard untuk meredakan inflamasi gingiva pada beberapa pasiennya, ternyata Gly-oxideTM yang mengandung karbamid peroksida $10 \%$ tidak hanya meningkatkan kesehatan ginggiva saja tetapi juga memutihkan giginya. ${ }^{4}$ Munro juga menemukan terjadinya pemutihan gigi pada pasien yang di skaling dan rootplaning dengan menggunakan karbamid peroksida, dan hasil temuannya dipresentasikan dan menghasilkan bahan pemutih gigi komersial yang pertama. Akhirnya bahan pemutih diproduksi untuk digunakan sendiri dirumah dengan biaya yang sangat murah. Karena popularitasnya meningkat banyak produk baru dengan variasi teknik termasuk produk yang dijual bebas dipasaran. Pada saat ini bahan pemutih yang sering digunakan adalah hidrogen peroksida dan karbamid peroksida. ${ }^{4}$

\section{Karbamid Peroksida}

Karbamid peroksida yang juga disebut nama urea hidrogen peroksida dengan rumus molekul $\mathrm{CH}_{2} \mathrm{~N}_{2} \mathrm{OH}_{2} \mathrm{O}_{2}$ dengan berat molekulnya 94,07 dan merupakan agen bleaching,anti septik dan desinfektans .Karbamid peroksida tidak berwarna ,tidak berbau,tidak toksik dan berbentuk kristal putih yang dapat larut dalam alkohol, eter dan air, merupakan kombinasi urea dan hidrogen peroksida ${ }^{5}$. Nama kimia karbamid peroksida yaitu karbamid urea,urea peroksida, perhydrol urea dan perhydelur. ${ }^{6}$

Secara kimia karbamid peroksida terurai menjadi $\mathrm{H}_{2} \mathrm{O}_{2}$ dan urea dalam larutan air, dan dapat dijelaskan sebagai berikut :

Karbamid peroksida $\rightarrow$ Hidrogen peroksida + urea

$$
\begin{array}{ll}
\mathrm{CH}_{2} \mathrm{~N}_{2} \mathrm{OH}_{2} \mathrm{O}_{2} & \rightarrow \mathrm{H}_{2} \mathrm{O}_{2}+\mathrm{CH}_{2} \mathrm{~N}_{2} \mathrm{O} \\
\text { Hidrogen peroksida } & \rightarrow \text { air }+ \text { oksigen } \\
\mathrm{H}_{2} \mathrm{O}_{2} & \rightarrow \mathrm{H}_{2} \mathrm{O}+\mathrm{O}_{2} \\
\text { Urea } & \rightarrow \text { Amonia }+ \text { karbondioksida } \\
\mathrm{CH}_{2} \mathrm{~N}_{2} \mathrm{O} & \rightarrow \mathrm{NH}_{3}+\mathrm{CO}_{2}
\end{array}
$$

Untuk meningkatkan pembentukan radikal perhidroksil, hidrogen peroksida di-buffer hingga PH mencapai 9,5-10,8. Proses buffer ini menghasilkan banyak radikal bebas yang akan bereaksi dengan ikatan tidak jenuh dan menyebabkan gangguan konjugasi elektron dan perubahan penyerapan energi pada molekul organik 
email, karena itu akan terbentuk molekul organik yang lebih kecil dengan warna yang lebih terang dan dengan demikian menghasilkan efek pemutihan yang lebih baik.'

Karbamid peroksida digunakan dua konsentrasi, yaitu konsentrasi tinggi yaitu 30\%-50\% yang dipakai untuk metode in-office bleaching, konsentrasi rendah yaitu $10 \%-16 \%$ yang di gunakan untuk metode night guard vital bleaching (home bleaching). ${ }^{1,4}$ Pada karbamid peroksida $10 \%$ mengandung 3,6\% hidrogen peroksida dan 6,4\% urea, sedangkan pada $35 \%$ karbamid peroksida setara dengan $12 \%$ hidrogen peroksida.

Karbamid peroksida terdiri dari unsur aktif yaitu hidrogen peroksida dan unsur non aktif seperti gliserin dan bahan penyegar (flavour), phosphoric, asam sitrat, trolamine, phenacetin dan air. Disamping itu juga dapat mengandung bahan lain sebagai campuran yaitu polimer karboksipolimetilen (karbopol) yang berfungsi sebagai penambah kekentalan dan daya lekat serta memperlambat proses pelepasan oksigen dari karbamide peroksida.Dengan demikian memungkinkan oksigen bereaksi lebih lama dengan elemen yang menimbulkan pewarnaan. ${ }^{1,7}$

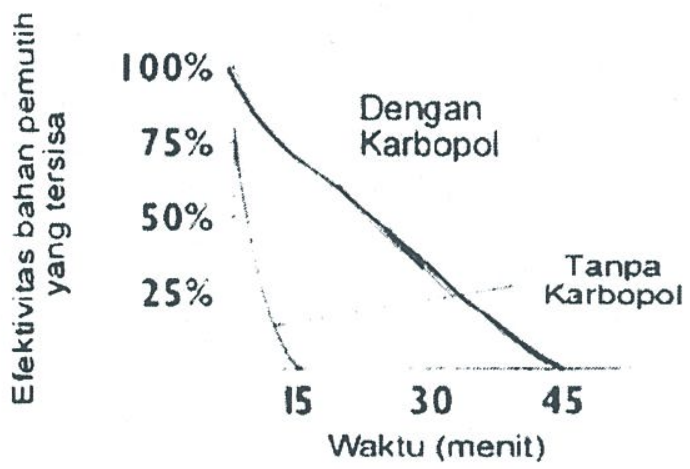

Gambar 1. Meningkatnya kekuatan bahan pemutih mengandung karbopol dibandingkan tanpa karbopol, ( Goldstein dan Garber 2000)

\section{Mekanisme Pemutihan Gigi}

Mekanisme pemutihan gigi merupakan reaksi oksidasi dari bahan pemutih. Peroksida sebagai agen oksidator mempunya radikal bebas yang tidak mempunyai pasangan elektron yang akan lepas dan kemudian diterima oleh email sehingga terjadi proses oksidasi. Elektron-elektron ini akan teroksidasi oleh bahan organik yang menyebabkan perubahan warna gigi. Radikal bebas dari peroksida adalah perhidroksil dan oksigenase. Perhidroksil ini merupakan radikal bebas yang kuat dan berperan pada proses pemutihan gigi, sedang oksigenase sebagai radikal bebas lemah. ${ }^{1,6}$ Pembentukan perhidroksil dapat ditingkatkan dengan menaikkan PH peroksida sampai 9,9-10,8, dan proses buffer ini dapat meningkatkan efek pemutihan.

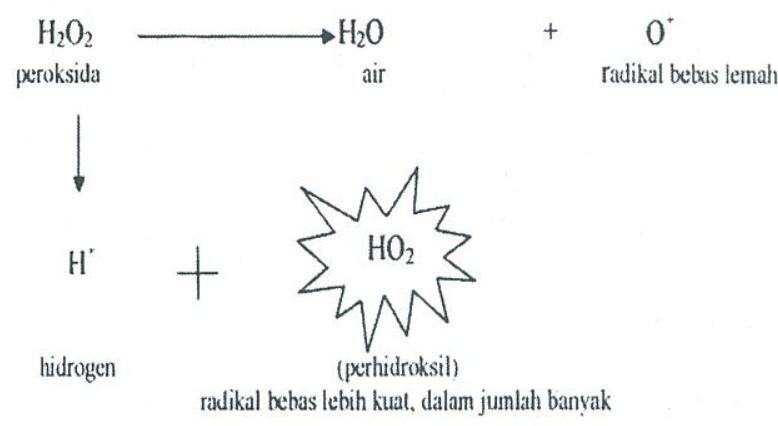

Gambar 2. Proses buffer menghasilkan banyak radikal bebas lebih kuat (prehidroksil) (Patil dalam Goldstein 2002)

Setelah terbentuk $\mathrm{HO}_{2}$ dalam jumlah banyak, maka akan bereaksi dengan ikatan tidak jenuh dan menyebabkan penyerapan energi pada molekul organik email dan akan terbentuk molekul organik email yang lebih kecil dengan warna yang lebih terang. Albers menyatakan bahwa pada awal pemutihan gigi cincin karbon yang terpigmentasi akan terbuka menjadi ikatan yang tidak jenuh dengan warna yang lebih terang. ${ }^{4}$

Pada karbamid peroksida $10 \%$ yang digunakan untuk home bleaching kandungan hidrogen peroksidanya adalah $3,6 \%$ dengan $6,4 \%$ urea. Hidrogen peroksida akan terurai menjadi oksigen dan air, dan urea akan terurai menjadi amonia dan karbondioksi.

Urea dalam karbamid peroksida berperan sebagai penstabil agar efek bahan tersebut lebih panjang dan berperan memperlambat pelepasan hidrogen peroksida. Agar efek karbamid peroksida maksimal, dibutuhkan waktu yang lama berkontak dengan gigi. ${ }^{8}$ Sementara itu ada yang menyatakan bahwa urea pada karbamid peroksida dapat bergerak bebas ke dalam email dan dentin pada saat proses degradasi ammonia, dan karbondioksida akan dilepas serta akan meningkatkan $\mathrm{PH}^{1,8}$ 


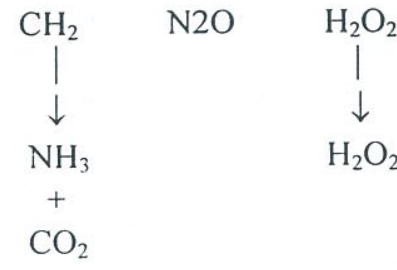

(jambar 3. Reaksi kimia penguraian karbamid peroksida.

(Goldstein dan Garber.2000)

Penambahan karbopol sebagai unsur pengental juga berpengaruh pada efektifitas kerja karbamid peroksida, karena menyebabkan daya lekat yang baik dan tidak mudah larut dalam saliva. Faktorfaktor yang mempengaruhi keberhasilan pemutihan gigi yaitu suhu, konsentrasi bahan pemutih dan lamanya berkontak dengan gigi. ${ }^{9} 10$

\section{Efek Karbamid Peroksida Terhadap Jaringan Keras Gigi}

Penggunaan bahan pemutih ini mempunyai titik jenuh, dimana proses pemutihan sudah tidak dapat efektif lagi dan apabila diteruskan akan menyebabkan pecahnya struktur anorganik email dan meyebabkan email menjadi rusak. ${ }^{11,12}$ Perdigao dkk (1998) melakukan penelitian efek karbamid peroksida $10 \%$ terhadap email dan hasilnya dapat menyebabkan penurunan jumlah kalsium, fosfat dan fluoride pada email ${ }^{13}$, dan akibatnya terjadi perubahan microhardness email. Walaupun pada penelitian lain disebutkan bahwa penurunan kalsium email dapat diimbangi oleh proses remineralisasi. Kekerasan email merupakan salah satu sifat fisik email yang dipengaruhi oleh banyaknya jumlah bahan anorganik seperti kalsium, dengan larutnya sebagian kalsium dari kristal hidroksi apatite maka kekerasan email menjadi menurun sehingga rentan terhadap terjadinya karies. ${ }^{14}$

Pada karabamid peroksida konsentrasi tinggi penurunan microhardness lebih besar dan cepat, yang disebabkan jumlah oksidator yang dilepas banyak, PH yang rendah sehingga rasio jumlah bahan organik dan anorganik terganggu dan terjadi kerusakan pada email. Oltu \& Gurgan menganalisa dengan menggunakan spektroskopi infrared dan sinar -x menemukan bahwa karbamid peroksida $35 \%$ mempengaruhi struktur email, sedangkan karbamid peroksida $10 \%$ dan $16 \%$ tidak mempengaruhi email selama enam minggu (8 jam/ hari $^{15}$.Akan tetapi pada penelitian yang dilakukan oleh Novandyta menghasilakn bahwa karbamid peroksida $35 \%$ yang diaplikasikan selama 1 jam dan 2 jam tidak menyebabkan kelarutan kalsium email. ${ }^{16}$

Berlawanan dengan penemuan Crew dkk (1997) menggambarkan peningkatan jumlah kalsium dan fosfat pada email yang dilakukan pemutihan dengan karbamid peroksida. Hal ini didukung bahwa defek mikrostruktural dapat diperbaiki oleh absorbsi atau pengendapan komponen saliva, seperti kalsium dan fosfat.Selain itu juga ada beberapa penemuan yang menyatakan bahwa gigi yang diputihkan dengan karbamide peroksida kekerasan emailnya dapat meningkat. ${ }^{7}$ Perubahan kekerasan email setelah diputihkan dengan karbamide peroksida tergantung pada produk yang digunakan dan tingkat keasamannya dan beberapa peneliti menyatakan bahwa pada $\mathrm{PH}$ 4,6-7,4 akan mempengaruhi struktur email. $^{13}$

\section{Efek Karbamid Peroksida Terhadap Jaringan Pulpa}

Karbamid peroksida dalam penggunaanya sebagai bahan pemutih gigi juga mempunyai efek samping terhadap jaringan lunak dan jaringan keras gigi Pada penelitian yang dilakukan Haywood dkk mendapatkan bahwa $34 \%$ dari subyek mengatakan giginya sensitive dan $13 \%$ gusinya yang sensitive. ${ }^{17}$ Bowles (1992) meyatakan bahwa rasa sensitive pada gigi akibat penggunaan bahan pemutih adalah disebabkan karena terjadi proses metabolisme glukosa dan sintesa protein, terutama kolagen, reaksi ini dipengaruhi oleh enzim tertentu yang sangat sesitif terhadap lingkungan dan ini yang menyebabkan gigi menjadi sensitive. ${ }^{18}$ Schulte (1994) pada studi invivo dengan teknik home bleaching dengan karbamid peroksida 10\% tidak menemukan perubahan pada jaringan pulpa yang bersifat irreversibel dengan cara ditest dengan elektrik pulp tester ${ }^{19}$.

Hipersensitif pulpa dipengaruhi oleh : faktor pasien, lamanya kontak dengan bahan pemutih, konsentrasi bahan, komposisi bahan, $\mathrm{PH}$ dan tray yang digunakan. Untuk mengatasi dentin hipersensitive yaitu dengan cara melakukan aplikasi fluor agar cairan tubuli dentin tidak mengalir karena fluor menutup lubang tubuli atau melakukan desensitasi pembuluh syaraf dalm tubuli dentin dengan menggunakan potasium nitrat. ${ }^{20}$ Potasium nitrat akan masuk kedalam tubuli dentin dan menempel pada pembuluh syaraf dan ion potassium 
akan mendepolarisasi saraf agar tidak terjadi polarisasi dan tidak ada penghataran rasa sakit ke otak. $^{20,21}$

\section{Efek Karbamid Peroksida Terhadap Jaringan Lunak}

Reaksi inflamasi pada jaringan lunak akibat penggunaan karbamid peroksida sebagai bahan pemutih dapat terjadi karena adanya reaksi redoks selama proses pemutihan, sehingga adanya radikal bebas oksigen dapat memecahkan membran sel epithel mukosa mulut beserta lapisan korneumnya. Pemecahan membran ini melalui proses oksidasi, pada keadaan kronis dapat menimbulkan peradangan pada gusi. ${ }^{22.23}$ Leonard (1977) melaporkan bahwa indeks ginggiva sebelum dan sesudah pemutihan gigi dengan karbamid peroksida $10 \%$ dengan teknik home bleaching terjadi perbedaan yang bermakna. ${ }^{23,24}$

\section{Kestabilan Warna Setelah Pemutihan}

Waktu yang dibutuhkan untuk memutihkan gigi bergantung kepada konsentrasi karbamid peroksida, lamanya aplikasi dan metode pemutihan.

Pada teknik home bleaching waktu aplikasi 2-8 minggu 6-8 jam/hari hasil pemutihan bisa 2-5 tingkat lebih putih $^{26} 1$ jam dan 2 jam tidak ada perbedaan bermakna. ${ }^{26}$ Stabilitas warna dapat bertahan 1-3 tahun $^{21}$ dan warna secara perlahan akan mejadi lebih gelap dan diperlukan perawatan ulang sekitar 1-4 hari dan pengulangan dapat dilakukan apabila pasien merasa giginya sudah berubah kembali. ${ }^{25}$ Penggunaan pasta gigi yang mengandung bahan pemutih juga dapat dianjurkan. Tenik in office bleaching menggunakan karbamid peroksida konsentrasi tinggi dengan waktu aplikasi 2 jam menghasilakn kenaikan tingkat warna 1-2 tingkat dan setelah dua minggu gigi akan menjadi lebih terang karena proses oksidasi masih berlangsung. Pemutihan dapat diulang apabila pasien merasa kurang optimal hasinya. Nurina yang meneliti lamanya waktu aplikasi karbamid peroksida 35\% terhadap efektifitas hasil pemutihan, ternyata antar aplikasi 1 jam dibandingkan dengan yang 2 jam hasil pemutihan tidak berbeda. ${ }^{26}$

\section{Seleksi Kasus}

Pemutihan gigi secara garis besar tidak ada kontra indikasi, akan tetapi perlu beberapa pertimbangan, seperti batasan umur dianjurkan 18 tahun ke atas ${ }^{10}$ hal ini mungkin berhubungan dengan kondisi pulpa yang akan teriritasi oleh bahan pemutih, pada gigi hipersensitif dan inflamasi ginggiva tidak dianjurkan karena menurut teori bahan pemutih ini dapat menimbulkan hipersensitif dan inflamasi ginggiva. Pada pasien yang mempunyai banyak restorasi terutama resin komposit karena karbamid peroksida mempengaruhi polimerisasinya, apabila restorasi akan diganti setelah proses pemutihan maka dianjurkan 2 minggu setelah pemutihan karena oksidator akan hilang setelah waktu tersebut. ${ }^{27}$ Kehilangan email seperti fluorosis,mottled email dan defek email merupakan kontra indikasi 1, karena bahan pemutih dapat mempengaruhi sifat fisik dan khemis email.

Pada wanita hamil dan menyusui tidak dianjurkan, walaupun belum ada penelitian yang membuktikan. ${ }^{1,6}$ Juga pada pasien yang mempunyai riwayat alergi terhadap obat-obatan perlu dilakukan test terlebih dahulu. Untuk yang mempunyai kebiasaan merokok dianjurkan menghentikan selama proses pemutihan dan 2 minggu setelah pemutihan dan yang paling penting pasien bersedia untuk menandatangi informed consent.

\section{Prosedur Pemutihan Dengan Karbamid}

Ada 2 prosedur untuk memutihkan gigi yaitu dengan metode in office bleaching dan home bleaching. Pada home bleaching bisa menggunakan obat yang dijual bebas atau prosedur pemutihan dibawah pengawasan dokter.

\section{Pemutihan dengan karbamid peroksida $\mathbf{1 0} \%$}

Teknik pemutihan gigi yang menggunakan karbamid peroksida $10 \%$ ialah teknik nightguard vital bleaching atau biasa disebut home bleaching. Prosedur ini dilakukan oleh pasien sendiri di rumah dibawah pengawasan dokter gigi. Teknik ini digunakan pada kasus perubahan warna yang ringan dengan menggunakan alat bantu berupa tray atau custem fitted tray ${ }^{1,28}$ yang fungsinya untuk menahan karbamide peroksida agar dapat berkontak dengan gigi selama proses pemutihan. ${ }^{4,17}$

Prosedur pemutihan gigi dengan karbamid peroksida $10 \%$ (home bleaching), pertama harus dilakukan pembersihan karang gigi dan stain pada gigi kemudian dilakukan penentuan warna gigi dengan menggunakan shade guide dan ditunjukkan kepada pasien dan bila perlu dilakukan pemotretan. Untuk keperluan pembuatan tray maka dilakukan 
pencetakan. Pada tray dibuat dengan reservoir pada bagian bukal dengan ketebalan $0,5 \mathrm{~mm}$ dengan batas servikal 1-1,5 mm dari servikal dan $1 \mathrm{~mm}$ dari oklusak/insisal untuk tempatnya bahan pemutih, batas tepi tray mengikuti bentuk gusi dan interdental papil untuk mencegah keluarnya bahan pemutih dari tray. Tray dibuat dari plastik vinil yang lentur yang dibuat dan dibentuk dengan alat vakum. Tray dicoba dan dilihat posisinya, kemudian tata cara penggunaan tray dijelaskan kepada pasien yaitu; sebelum pemutihan gigi harus dalam keadaan bersih, bahan pemutih diletakkan di resevoir secukupnya kemudian tray dimasukkan kedalam mulut dengan cara digigit secara perlahan sampai pas, kelebihan bahan pemutih pada ginggiva dibuang dengan menggunakan sikat gigi yang halus dan prosedur ini dilakukan pada malam hari saat tidur selama 6-8jam karena pada malam hari aktifitas mulut dan aliran ludah paling sedikit. Setiap selesai pemakaian harus tray dibersihkan. Proses pemutihan dapat berlangsung 7-14 hari tergantung pada warna yang dikehendaki. Apabila ada rasa sensitive pada gigi dan ginggiva maka pemutihan dapat dihentikan lebih dahulu sampai sembuh dan pemutihan dapat dilanjutkan.

\section{Teknik pemutihan dengan karbamid peroksida} $35 \%$ (in office bleaching)

Prosedur sama seperti pada home bleaching, tetapi konsentrasi karbamide peroksida yang digunakan $35 \%$ dan aplikasi selama 2 jam diruang praktek dokter gigi, dan hanya satu kali pemakaian dan dapat diulang setelah 2 minggu.

Teknik pemutihan gigi dengan produk yang dijual bebas

Produk yang beredar bisa dalam bentuk gel,cair, atau pasta gigi. Tetapi produk-produk yang ada semuanya jarang mencantumkan konsertrasinya, sehingga dari segi keamanan sangat meragukan. 11.Pada produk berbentuk gel penggunaanya mirip seperti home bleaching ,akan tetapi tray hanya berukuran S,M,L sehingga tidak dapat pas dan kebocoran bahan pemutih sangat memungkinkan, efektifitas berkurang karena tercampur dengan saliva dan iritasi pada ginggiva mudah terjadi.

\section{Ringkasan}

1. Bahan pemutih gigi karbamid peroksida digunakan dalam 2 konsentrasi yaitu : konsentrasi rendah $10 \%-15 \%$ dan konsentrasi tinggi $35 \%$.

2. Cara aplikasi yaitu home bleaching dan in office bleaching.

3. Waktu aplikasi home bleaching 2-6 minggu dan $8 \mathrm{jam} / \mathrm{hari}$, in office bleaching $2 \mathrm{jam}$.

4. Hasil pewarnaan dapat meningkat berkisar 2-5 tingkat.

5. Stabillitas warna dapat bertahan 1-3 tahun.

6. Perawatan pemutihan gigi dapat diulang.

7. Karbamid peroksida cukup aman digunakan sebagai bahan pemutih gigi jika dilakukan sesuai prosedur.

8. Efek terhadap jaringan keras gigi dan jaringan lunak sekitar gigi pernah dilaporkan.

\section{Daftar Pustaka}

1. Goldstein RE, Garber DA. Complete dental bleaching. London Quintessence Publishing Co.Inc; Chicago. 1955:2-20.

2. Grossman LL, Oliet S. Ilmu Endodontik dalam praktek. $11^{\text {th }}$ ed. ECG.1995:295-301.

3. Schwenk MD. Cosmetic tooth whitening; ADTS; 1-6.

4. Mc.Laughlin G, Freedman GA. Color Atlas of Tooth Whitening. Tokyo Ishiyaku Euro America Inc. 1991.

5. Baisden, Michael K. Comparisson of $10 \%$ Carbamide Peroxide and Sodium Perborate for intra coronal bleaching. In: General Dentistry. May-Jun 2000.

6. Patil R. Esthetic dentistry; An Artist's science.PR Publications, Mumbai 2002: 83-92.

7. Basting RT. The effect of $10 \%$ carbamide peroxida bleaching material on microhardness of sound and demineralized enamel and dentin in situ.Operative Dentistry 2001; 26:531-9.

8. Tam LE. Clinical trial of three 10\% carbamide peroxide bleaching product. Journal of Canadian Dental association 1999; 65: 201-5.

9. Tam LE. The safety of Home Bleaching Techniques Journal of the Canadian Dental Association. 1999; 65:453-5.

10. Matis BA. Tray whitening; What the evidence shows.Compendium 2003; 24(4A): 354-62.

11. Kelleher MGD, Roe FJC. The safety-in use of $10 \%$ carbamide peroxide (opalescence) for bleaching teeth under the supervision of dentist.British Dental Journal 1999; 187(4):190-4. 
12. ADA Org. Oral health topics:Tooth whitening treatments frequently asked questions. http://www.ada org/public/topic/whitening.

13. Ahmad, Irfan. Three-dimensional Shade Analysis; Perpectives of Color. In: Practical Periodontics Aesthetics Dentition. 2000; (12): 557-62.

14. Attin T. Susceptibility of Enamel Surfaces to Demineralization after Application of Fluoride Karbamide Peroxide Gels. In: Caries research 2003; (37): 93-9.

15. Li, Yiming. Peroxide Containing Tooth Whiteners: An Update on Safety.In:Compedium 2000; (21).

16. Novandyta. Pengaruh waktu karbamid peroksida $35 \%$ terhadap kelarutan kalsium email. Skripsi S1 FKGUI 2005.

17. Haywood VB et al. Effectiveness, side effect and long term status of nightguard vital bleaching. JADA 1994; (25): 1219-26.

18. Bowles et al. Pulp Chamber penetration by hidrogen peroxide following vital bleaching procedur.J Endodontics 1992; 18: 315-7.

19. Schulte JR. The effect of bleaching application time on the dental pulp JADA 1994; 125: 1330-5.

20. Jacobsen PL et al. Clinical dentin hypersensitivity: understanding the causes and prescribing $a$ treatment. The Journal of Contemporary dental practice $2001 ; 2(4): 1-8$.

21. Haywood VB. Frequently asked questions about bleaching. Compedium 2003; 24(4A): 324-38.

22. Gunawan H. Pengaruh bahan pemutih gigi karbamid peroksida terhadap mukosa rongga mulut secara mikroskopik (penelitian pada tikus wistar strain LMR) Journal Ked.Gigi UI Jakarta 2003; (10): 652-6.

23. Leonard RH. Haywood VB. Risk factors for developing tooth sensitivity and ginggival iritation associated with nightguard vital bleaching. Quintessence International 1997; 28 (8): 527-34.

24. Leonard RH. Efficacy, longevity, side effects, and patient percepsions of nightguard vital bleaching Compend Contin Educ Dent 1998; 19: 766-81.

25. Neiderman $\mathrm{R}$ et al. Effectiveness of dentistprescribed, home-applied tooth whitening. A metaanalysis. The Journal of contemporary dental practice 2000; 1(4): 20-37.

26. Nurina. Pengaruh waktu aplikasi karbamid peroksida $35 \%$ terhadap hasil pemutihan gigi. Skripsi S1 FKGUI 2005.

27. Bailey J Shawn. Effect of home bleaching product on composite resin. Quintessence Int.199223;23:489-94.

28. Haywood VB. Current status of nightguard vital bleaching. In Compendium 2000; (21): 10-7. 